\title{
PERBANDINGAN SATO IMO DAN TEPUNG TERIGU DALAM PENGOLAHAN MIE SATO IMO DENGAN FORTIVIKASI KLOROFIL
}

\section{COMPARISON OF SATO IMO AND WHEAT FLOUR IN SATO IMO NOODLE PROCESSING WITH CHLOROPHYLL FORTIVICATION}

\author{
Riswan Mulyadi ${ }^{1)}$, Andwini Prasetya ${ }^{2)}$, Lina Widawati ${ }^{3)}$ \\ 1) Teknologi Pangan Fakultas Pertanian UNIVED \\ 2) Teknologi Pertanian Fakultas Pertanian UNIVED \\ 3) Fakultas Pertanian UNIVED
}

\begin{abstract}
ABSTRAK
Sato Imo atau talas jepang merupakan umbi-umbian yang dapat diolah menjadi produk pangan salah satunya adalah mie. Untuk membuat mie Sato lmo, Sato lmo dikukus terlebih dahulu, dilakukan penghalusan, pencampuran, pencetakan dan pemasakan. Tujuan dari penelitian ini untuk mengetahui pengaruh perbandingan Sato lmo dan tepung terigu dalam pembuatan mie Sato lmo dengan penambahan ekstrak bayam terhadap tingkat kesukaan konsumen berdasakan parameter warna, rasa, dan kekenyalan mie Sato lmo. Proses pengolahan Mie Sato Imo dilakukan dalam 3 perlakuan yaitu perbandingan Sato Imo dan tepung terigu : 200 gram : 800 gram , 300 gram : 700 gram, 400 gram : 600 gram. Analisis yang dilakukan dalam penelitian ini adalah analisis organoleptik. Dari hasil uji organoleptik menunjukkan bahwa mie Sato lmo yang paling disukai dari segi parameter warna yaitu pada perlakukan perbandingan Sato Imo dan tepung terigu 200 gram : 800gr dengan nilai 1,81 (Suka). Untuk parameter rasa yaitu pada perlakuan perbandingan Sato Imo dan tepung terigu 400 gram : 600 gram dengan nilai 2,21 (suka). Untuk parameter kekenyalan panelis lebih menyukai mie Sato Imo dengan perbandingan Sato Imo dan tepung terigu 400 gram : 600 gram dengan nilai 2,37 (suka).
\end{abstract}

Kata Kunci : Sato Imo, Mie Sato Imo, Uji Organoleptik

\section{ABSTRACT}

Sato Imo, or Taro Japanese are tubers which can be processed into food products one of which was noodle. To make the noodles "Sato Imo", Sato lmo first steamed, smoothing is done, mixing, molding and cooking. The purpose of this study was to determine the effect of comparison Sato lmo and wheat flour in making noodles Sato lmo with the addition of spinach extract on the level of consumer preference parameters based on the color, flavor, and firmness of noodles Sato Imo. The processing is done in the Mie Sato Imo the 3 treatment comparisons Sato Imo and wheat flour : 200 grams : 800 grams, 300 grams : 700 grams, 400 grams : 600 grams. The analysis conducted in this study is the organoleptic analysis. From the results of organoleptic test showed that the noodles Sato lmo most preferred in terms of color parameters, namely the treatment comparison Sato Imo and wheat flour 200 grams : 800gr with a value of 1.81 (likes). For a sense of the parameters of the treatment comparison Sato Imo and 400 grams of wheat flour : 600 grams with a value of 2.21 (likes) . For the elasticity parameter panelists preferred the noodles with comparison Sato Sato Imo Imo and 400 grams of wheat flour: 600 grams with a value of 2.37 (likes ).

Keywords : Sato Imo, Mie Sato Imo, Organoleptic Test 


\section{PENDAHULUAN}

Isu krisis pangan yang menerpa beberapa negara berkembang, ternyata belakangan ini juga santer beredar di negara kita. Tingginya lajuimpor beras yang dilakukan pemerintah untuk memenuhi pasokan bahanpangan diIndonesia, tentunya memicu protes keras dari berbagai kalanganmasyarakat. Tidaklah heran bila berkaca dari protes tersebut pemerintahmulai mencanangkan program diversifikasi pangan, agar tidak selamanyabergantung pada beras.

Dengan konsep menggali keaneakaragam pangan lokal sebagaipengganti beras, secara ilmu gizi tidak ada perbedaan dan pengaruhburuknyajika mengganti beras dengan sumber bahan makanan pokok lain.Salah satunya saja seperti umbi talas yang mulai digadang-gadangmasyarakat sebagai sumber karbohidrat pengganti nasi yang hargajualnya relative cukup murahjikadikonsumsi sebagai makananpokok setiap harinya.

Umbi talas atau yang memiliki nama ilmiah Colocasia esculenta L.ini memang sangat potensial jika dijadikan sebagai salah satu sumberkarbohidrat murah pengganti nasi. Kandungan proteinnya yang lebih tinggidari ubijalar dan singkong, serta kandungan karbohidratnya yang mencapai 77,9 \%,mendorong masyarakat kita untuk mulai mengolah umbi talas menjadi beragam jenis olahan makanan. Baik itu diolah menjadi makanan pokok pengganti nasi, maupun diolah menjadi beragam jenis makanan ringan.

Saat ini, di pasaran banyak dijual beragam jenis umbi talas, seperti talas bogor, talas pandan, talas mentega, talas ketan dan talas loma.Masing-masing talas ini memiliki bentuk dan cita rasa yang berbeda-beda. Rasa enggan mengkonsumsi talas adalah karena disinyalirmenimbulkan rasa gatal-gatal di tenggorokan. Kalsium oksalat yangmenimbulkan rasa gatal tersebut dapat direduksi dengan cara melakukanpemasakan hingga benar-benar matangatau merendam talas di dalamlarutan asam klorida sebelum dimasak menjadi beragam jenis makananolahan talas (Indri,2013).

Mie talas merupakan salah satujenis olahan terbaru dari penggunaan talas. Mie saat ini selain sebagai makanan tambahan namun juga dapat dijadikan sebagai bahan makanan pengganti karbohidrat selain nasi. Hal ini dikarenakan kandungan gizi yang terdapat dalam mie talas. Tepung terigu sebagai bahan utama kedua dalam pembuatan mie talas ini jugamengandung banyak karbohidrat dan protein. Selain kedua bahan utama diatas, bahan tambahan lainnya dalam pembuatan mie talas ini jugamengandung nilai gizi yang 
beragam untuk saling melengkapi hinggaterciptanya makanan yang kaya akan gizi. Bahan tambahan yang digunakanadalah telur (protein hewani),garam (yodium), dan ekstrak bayam (klorofil dan zat besi).

\section{METODE PENELITIAN}

\section{Bahan dan Alat}

Bahan-bahan dalam pembuatan mie ini adalah sato imo yangdidapat dari hasil kebun di Kepahiang, tepung terigu, air, telur, garam,ekstrak bayarn, minyakgoreng, bawang merah dan bawang putih. Alat-alat yang akan digunakan dalam proses pembuatan mie iniadalah baskom, mesin markatto (alat pencetak dan pemotong mie), kuali,kompor, sendok, penyaringan, plastik, ayakan, lumbung (untuk menumbuk sato imo) dan pisau.

\section{Metode}

Tahapan-tahapan penelitian dalam pebuatan mie sato imo meliputi pembuatan tepung sato imo, penyiapan ekstrak bayam dan pembuatan mie sato imo. Perlakuan pada penelitian ini yaitu perbandingan Sato Imo dengan tepung terigu yaitu 200 gram : 800 gram; 300 gram : 700 gram; 400 gram: 600 gram.

Analisis yang digunakan adalah analisis tingkat kesukaan dengan 80 orang konsumen/responden dengan parameter penilaian meliputi warna, rasa, kekenyalan dengan skala penilaian $1=$ Suka Sekali; $2=$ Suka; 3 = Agak Suka; 4 = Tidak Suka; $5=$ Sangat Tidak Suka

\section{HASIL DAN PEMBAHASAN}

Dari hasil uji orgonoleptik berdasarkan perameter warna, rasa dan kekenyalan pada mie sato imo, maka diperoleh hasil seperti tertera pada tabel 1

Tabel 1. Rerata Tingkat Kesukaan Panelis terhadap Mie Sato Imo

\begin{tabular}{cccc}
\hline & \multicolumn{3}{c}{ Perbandingan tepung Sato Imo dan Tepung Terigu } \\
\cline { 2 - 4 } Atribut Mutu & 200 gr: 800 gr & 300 gr: 700 gr & 400 gr :600 gr \\
\hline Warna & 1,81 & 1,82 & 2,75 \\
Rasa & 2,44 & 2,41 & 2,21 \\
Kekenyalan & 2,66 & 2,52 & 2,31 \\
\hline
\end{tabular}

Ket: 1. Suka sekali, 2. Suka, 3. Agak suka, 4. Tidak suka, 5. Sangat tidak suka

Dari tabel 1 diatas terlihat bahwa tingkat kesukaan konsumen terhadap mie sato imo, dengan parameter warna pada perlakuan 200 gram : 800 gram, untuk parameter rasa panelis memilih mie pada perlakuan 400 gram : 600 gram, dan untuk 
kekenyalan panelis memilih mie sato imo pada perlakuan 400 gram: 600 gram.

\section{Warna}

Dalam menentukan mutu pangan pada umumnya sangat bergantung pada beberapa faktor diantaranya warna, rasa dan tekstur. Sebelum faktor-faktor lain, secara visual faktor warna tampil terlebih dahulu dan kadang-kadang sangat menentukan. Daya tarik suatu jenis makanan lebih sering dipengaruhi oleh kenampakan warna sebagai salah satu sifat. Kenampakan mempunyai peran penting dalam menentuka mutu pangan. Selain sebagai faktor yang ikut menentukan mutu, warna juga dapat digunakan sebagai indikator kesegaran atau kematangan. Baik tidaknya cara pencampuran atau pengolahan dapat ditandai dengan adanya warna yang seragam dan merata (Soekarto, 1985). Warna merupakan sifat tampak dan dapat dilihat oleh mata dan sebagai penentu mutu suatu produk. Pada umumnya memiliki produk warna yang terlebih dahulu yang dinilai sebelum faktor-faktor yang lain.Selain sebagai penentu mutu, warna sebagai indikator kesegaran ataukematangan. Baik tidaknya cara pencampuran atau cara pengolahan dapatditandai dengan adanya warna yang seragam dan merata (Anonim, 2009).Dalam pembuatan mie sato imo ini adonan menggunakan pewarna alami yang diambil dari ekstrak bayam.

Tabel 2. Rerata Tingkat Kesukaan Penelis Terhadap Parameter Warna Sato Imo

\begin{tabular}{cccc}
\hline & \multicolumn{3}{c}{ Perbandingan Sato Imo dan Tepung Terigu } \\
\cline { 2 - 4 } Atribut Mutu & $200 \mathrm{gr}: 800 \mathrm{gr}$ & $300 \mathrm{gr}: 700 \mathrm{gr}$ & $400 \mathrm{gr}: 600 \mathrm{gr}$ \\
\hline Warna & & & 1,82 \\
\hline
\end{tabular}

Ket: 1. Suka sekali, 2. Suka, 3. Agak suka, 4. Tidak suka, 5. Sangat tidak suka

Tabel 3. Anova Berdasarkan Warna

\begin{tabular}{cccccc}
\hline SV & DB & JK & MS & F Hitung & F Tabel \\
\hline Panelis & 79 & 61,8 & 0,78 & 0,86 & 1,36 \\
Perlakuan & 2 & 5,66 & 2,8 & 3,12 & 3,06 \\
Eror & 158 & 143,34 & 2,83 & & \\
Total & 239 & 210,8 & 0,91 & & \\
\hline
\end{tabular}

F Hitung $<\mathrm{F}$ tabel : berbeda nyata

F Hitung $>$ F tabel : tidak berbeda nyata

Dari tabel 2 diatas terlihat bahwa panelis lebih banyak menyukai warna mie sato imo dengan perbandingan sato imo dan tepung terigu 200 gram : 800 gram karena memiliki kecerahan yang baik, pada perbandingan sato imo dan tepung terigu 300 gram : 700 gram warna mie sota imo yang dihasilkan kurang kuning. Sedangkan 
pada perlakuan perbandingan sato imo dengan tepung terigu 400 gram : 600 gram warna yang dihasilkan agak pucat. Hal ini dikarenakan komponen yang ada dalam tepung terigu dapat membuat perubahan warna pada ke 3 perlakuan tersebut. Tepung terigu banyak digunakan sebagai bahan dasar berbagai macam produk olahan seperti sato imo. Tepung terigu merupakan tepung dengan warna yang putih kekuningan yang memberikan kontribusi warna putih kekuningan pada mie sato imo. Semakin banyak tepung terigu warna pada sato imo lebih kuning dibandingkan dengan mie yang lebih banyak menggunakan tepung terigu warna pada sato imo. Dari tabel diatas dapat disimpulkan bahwa penelis menyukai warna sato imo dengan perlakuan perbandingan tepung sato imo terhadap tepung terigu 200 gram: 800 gram. Dari tabel 3 diatas terlihat bahwa perlakuan yang diberikan berbeda nyata terhadap warna sato imo.

\section{Rasa}

Rasa adalah indra pengecap, dalam kepekaan rasa maka rasa manis dapat dengan mudah dirasakan pada ujung lidah, rasa asin dapat dirasakan pada ujung dan pinggir lidah, rasa asam pada pinggir lidah, rasa pahit pada bagian belakang lidah. Rasa biasanya ditentukan oleh salah satu zat dominan dan bersifat professional dalam susunan zat-zat yang memberikan rasa. Cita rasa juga sangat mempengaruhi derajat penerimaan konsumen (Winarno, 1995). Rasa merupakan faktor yang kedua yang mempengaruhi cita rasasebuah produk makanan setelah penampilan makan itu sendiri. Rasamerupakan tanggapan indra pengecap (lidah), terhadap rangsangan kimiawiseperti manis, asam, asin,

pahit.

Tabel 4. Rerata Tingkat Kesukaan Penelis Terhadap Parameter Rasa Sato Imo Atribut Mutu $200 \mathrm{gr}: 800 \mathrm{gr} \quad 300 \mathrm{gr}: 700 \mathrm{gr} \quad 400 \mathrm{gr}: 600 \mathrm{gr}$

$\begin{array}{ccc}2,44 & 2,41 & 2,21 \\ \text { kali, 2. Suka, 3. Agak suka, 4. Tidak suka, 5. Sangat tidak suka }\end{array}$

Tabel 5. Anova Berdasarkan Parameter Rasa

\begin{tabular}{cccccc}
\hline SV & DB & JK & MS & F Hitung & F Tabel \\
\hline Panelis & 79 & 64,32 & 0,81 & 2,79 & 1,36 \\
Perlakuan & 2 & 3,60 & 1,8 & 6,20 & 3,06 \\
Eror & 158 & 1333,07 & 0,29 & & \\
Total & 239 & 200,9 & & & \\
\hline
\end{tabular}

F Hitung $<$ F tabel : berbeda nyata

F Hitung $>$ F tabel : tidak berbeda nyata 
Dari tabel 4 rerata diatas dapat dilihat bahwa penelis lebih menyukai rasa mie sato imo dengan perlakuan perbandingan sato imo dengan tepung terigu 400 gram : 600 gram. Hal ini dikarenakan semakin banyak sato imo yang ditambahkan maka rasa yang dihasilkan khas sato imo yaitu sedikit manis. Dimana perpaduan rasa manis dan gurih akan menghasilkan rasa yang enak. Rasa manis ini berasal dari kandungan karbohidrat talas jepang atau sato imo yang sudah dikukus. Menurut Direktorat Gizi (1979), talas kukus memiliki kandungan karbohidrat 28,2 gram/ 100 gram. Sedangkan pada perlakuan perbandingan sato imo dan tepung terigu 200 gram : 800 gram dan 300 gram : 700 gram, sato imo yang digunakan lebih sedikit sehingga kurang mempengaruhi rasa pada mie tersebut.

Dari tabel 5 diatas panelis menilai ada pengaruh yang nyata antara 3 sampel yang di uji. Segi perlakuan juga berbeda sehingga panelis bisa menilai bahwa adanya perbedaan dari perlakuan diatas. Dalam penilaian rasa suatu pengaturan terhadap citarasa menunjukan penerimaan konsumen terhadap suatu produk makanan umumnya dilakukan dengan alatindra manusia. Dan rasaditimbulkan oleh zat yang dominan dan bersifatprovesional dalam susunanzatzat yang memberikan rasa. Cita rasa jugadapat mempengaruhi derajad penerimaan konsumen terhadap suatu produk makanan (Hastuti, 1998). Sato imo memiliki kandungan karbohidrat, protein, lemak yang mempengaruhi rasa pada mie, jadi semakin banyak tepung sato imo rasapada mie semakin terasa.

\section{Kekenyalan}

Kekenyalan merupakan faktor ketigapada mie, dimana mie sato imo dapat mempertahankan bentuk setelah mendapatkan perlakuan, tidakmudah putus dan mie yang kenyal pada saat mie dikunyah atau tekstur suatu penaganan akan sangat mempengaruhi tingkat penerimaan masyrakat. Kekenyalan disebabkan kandungan gluten yang dihasilkantepung terigu yang yang memiliki sifat elastis gluten yang jugamerupakan bahan pegikat,menyebakan mie tidak mudah putus pada saatmie mendapatkan perlakuan (Anonim, 2013).

Tabel 6. Nilai Rerata Tingkat Kesukaan Panelis Berdasarkan Parameter Kekenyalan Mie Sato Imo

\begin{tabular}{lccc}
\hline & \multicolumn{3}{c}{ Perbandingan Sato Imo dan Tepung Terigu } \\
\cline { 2 - 4 } Atribut Mutu & $200 \mathrm{gr}: 800 \mathrm{gr}$ & $300 \mathrm{gr}: 700 \mathrm{gr}$ & $400 \mathrm{gr}: 600 \mathrm{gr}$ \\
\hline Kekenyalan & 2,31 & 2,52 & 2,66 \\
\hline Ket: 1. Suka sekali, 2. Suka, 3. Agak suka, 4. Tidak suka, 5. Sangat tidak suka
\end{tabular}


Tabel 7. Anova Berdasarkan Parameter Kekenyalan

\begin{tabular}{cccccc}
\hline SV & DB & JK & MS & F Hitung & F Tabel \\
\hline Panelis & 79 & 47,9 & 0,61 & 1,30 & 1,36 \\
Perlakuan & 2 & 3,31 & 1,66 & 3,53 & 3,06 \\
Eror & 158 & 116,69 & 0,47 & & \\
Total & 239 & 167,9 & & & \\
\hline
\end{tabular}

F Hitung $<\mathrm{F}$ tabel : berbeda nyata

F Hitung $>$ F tabel : tidak berbeda nyata

Dari tabel 6 diatas terlihat bahwa tingkat kesukaan konsumen terhadap kekenyalan mie sato imo dengan perbandingan sato imo dengan tepung terigu 200 gram : 800 gram yaitu dengan nilai 2,31 (suka). Hal ini karena semakin sedikit penambahan sato imo kekenyalan semakin tinggi atau semakin elastis. Sedangkan semakin banyak penambahan sato imo maka mie tidak terlalu kenyal atau kurang elastis dan mudah putus. Hal ini disebabkan karena kandungan gluten pada tepung terigu yang memberi kontribusi elastisitas atau tekstur yang kenyal. Menurut Koeswara (2009) Tepung terigu berfungsi membentuk struktur mie, sumber protein dan karbohidrat. Kandungan protein utama tepung terigu yang berperan dalam pembuatan mie adalah gluten. Gluten dapat dibentuk dari gliadin (prolamin dalam gandum) dan glutenin. Protein dalam tepung terigu untuk pembuatan mie harus dalam jumlah yang cukup tinggi supaya mie menjadi elastis dan tahan terhadap penarikan sewaktu proses produksinya. Dari tabel 7 diatas panelis menilai ada pengaruh yang nyata antara
3 sampel yang di uji. Segi perlakuan juga berbeda sehingga panelis bisa menilai bahwa adanya perbedaan dari perlakuan diatas.

\section{SIMPULAN}

Dari hasil penelitian dapat disimpulkan bahwa berdasarkan parameter warna, mie sato imo yang paling disukai adalah mie sato imo dengan perbandingan komposisi sato imo dengan tepung terigu200 gram : 800 gram dengan nilai 1,81 (suka). Berdasarkan parameter rasa, mie sato imo yang paling disukai adalah mie sato imo dengan perbandingan komposisi sato imo dengan tepung teigu 400 gram : 600 gram dengan nilai 2,21 (suka). Berdasarkan parameter kekenyalan, mie sato imo yang paling disukai adalah mie sato imo dengan perbandingan komposisi sato imo dengan tepung terigu 200 gram : 800 gram dengan nilai 2,31 (suka).

\section{DAFTAR PUSTAKA}

Anonim, 2009, UjiOrganoleptik, http://id.wikipedia Diakses tanggal 20 2013.
April 
Anonim, 2013, Usaha Mie AyamTalas, UnlkRasanyaLezatOmzetnya(Resep diambildati www.sajiansedap.com), http://bisnisukm.comlusaha-mieayam-talas-unik-rasanya-lezaromzetnya.html, diaksestanggal 9 Juli 2013.

Indri, 2013, KbasiatSatoimo (TalasJepang), http://indriarahayu.blogspot.com/ 2013/05/khasiat-satoimo-talasjepang.html, diakses tangga19 Juli 2013.
Koswara, Sutrisno. 2009. Teknologi Pengolahan Mie. eBook Pangan.com. http:/tekpan.unimus.ac.id/wpcontent/uploads/2013/07/Teknologi -Pengolahan-Mie-teori-danpraktek.pdf

Soekarto,S.T, 1985. Penilaian Industri Pangan dan Hasil Pertanian. Bina Angkasa. Jakarta

Winarno, F.G. 1995. Kimai Pangan dan Gizi. Gramedia Pustaka Utama. Jakarta 